\title{
What does it mean to do Biology in the age of extinction?
}

\author{
Kaustubh Rau \\ School of Arts and Sciences, Azim Premji University, Bangalore, INDIA \\ kaustubh.rau@apu.edu.in
}

\begin{abstract}
This essay asks the question, do biologists have a added responsibility in responding to the climate emergency within the context of their discipline? If yes, what is the kind of Biology that should be practised going forward and what are the changes we should make to reduce carbon emissions as a community? I end the essay with possible answers to these questions.
\end{abstract}

In an undergraduate class on Introductory Biology we are discussing the effects of climate change on plants. The class and I talk about how rates of photosynthesis have shot up and its interplay with photorespiration. How nitrogen uptake in plants is reducing, decreasing the nutritional content of food crops. I also tell them about a friend observing large scale forest dieback in the shola forests of South India, likely caused by rising temperatures [1]. I scan the faces of the students as these topics are broached, but don't detect any reaction from them. In what is now a familiar routine, for every new topic that is introduced, I also give them the dire climate change perspective - but the students seem to take it in their stride. Perhaps they have become numb to the cataract of wretched information that they are daily faced with. Or perhaps not responding is a way of dealing with a truth that is so awful that any response seems woefully inadequate.

The question of planetary ecological collapse (summarized most recently by Lovejoy) [2], remains with me in whatever I do as a biologist these days. It is not clear what one's response as a professional biologist should be. Does some special responsibility accrue to biologists in grappling with this question, as opposed to physicists, chemists and mathematicians (or for that matter social scientists)?

While clearly on a human level we share responsibility equally for dealing with this crisis, on a disciplinary level it does seem to me to call forth a special response from biologists. For there is a paradox in the fact that biologists are studying the very thing that is fast disappearing from their world - no other discipline seems to have that unique problem.

What then should be our response? Biologists have already tried to raise consciousness in the community on making more sustainable choices (e.g. flying less) [3], [4]. Other initiatives such as launching new journals (Cell Press: One Earth, New Phytologist: Plants, People, Planet, Nature Sustainability, Nature Climate Change) seem on one level very worthy, but on another seem to me a cynical response ('it is now time for sustainability so let us put out a new journal'). I am not the first person to draw attention to the proliferation of journals [5] and more sophisticated reasoning indicates that a focus on journal impact factors might end up distorting scientific facts [6].

However my issue is more that these new journals posit concerns of ecological collapse and sustainability as separate from the mainstream biology that is practiced by biologists. This immediately 
creates a division within the discipline, with cell and molecular biologists thinking that it is the ecologists and conservation biologists' problem to think about these matters. Recently there have been shifts, with for instance colleagues in cognitive sciences creating frameworks and teaching resources for understanding the climate crisis [7].

However, gentle suggestions of flying less, using energy efficient appliances in the lab or offsetting your carbon credits seem to me to be falling well short of what is being asked for (nothing less than saving the planet). Indeed, we still seem to be worried about whether not attending conferences will negatively impact our careers and productivity [8].

Scientists are under no compulsion to fly less when fundamentally the business of biology hasn't undergone any change - in its funding, in its research impetus or in its rewards and incentives. Survey any group of biologists and their concerns remain the same, publishing the next big thing in their field, grant writing and getting papers accepted to prestigious journals. Certainly in India the 'ecosystem' of biological research hasn't shown any changes to account for the fact that species extinction and Himalayan glacier retreat is happening at an alarming rate[9].

But solutions, while important, aren't what I am not talking about. I think there is probably no dearth of solutions if we were to try to reduce biodiversity loss, carbon emissions and be more sustainable. There may be many kinds of solutions and I think if made a priority we will see many imaginative ones come about naturally. (I have listed a few of my own for carbon emissions reduction at the end of the article). Indeed, academicians driving the Extinction Rebellion movement are on the front-line in asking for direct action to combat climate change[10, 11].

Instead, I am talking about a need to change our thinking patterns when viewing the natural world. Recognizing that we and every other creature is a part of it, from the mighty sequoia and eucalypts to the knockout mice we study in the lab. (Amazingly, even these creatures although completely inbred without having seen the light of day still display some measure of their natural instincts).

We seem to have got where we are because of a separateness that is ingrained into the very framework of biology. We are not the creature we study and so we needn't feel anything for it. But it is enough like us for us to study its processes and improve our understanding of ourselves. In such a scenario it is obvious that we won't feel any compunction in using science and technology to breed the world's most successful biped in the form of the broiler chicken [12].

How then should we go about doing/creating a different kind of biology? Or is it a quixotic notion to even ask such a question? Is science still the 'endless frontier' [13] and will continue to be so? Shouldn't Vannevar Bush's report serve as a cautionary and signpost for us, because while it recommended using science for public welfare it famously led to the rise of the military-industrial complex.

The climate emergency indicates that there needs to be a transformation in the nature of science in the present century. We need to question deeply our relationship with nature, and the reasons for science playing a part in fostering our disconnect with it. It means asking individually and as a collective why am I/we studying the things that I/we am studying? It means acknowledging the living entity under the cross-hairs, its right to be on this earth and letting this understanding permeate our beings. This acknowledgement could then lead to new avenues of research. Perhaps, the organism we study could actually be a collaborator as found out by scientist Monica Gagliano[14].

Sydney Brenner once said biologists only ask three questions of a living organism: how does it 
work? How is it built? And how did it get that way?[15].

The time has come to ask a different set of questions. How do I recognize the rights of all living organisms to live on this earth? How can I ensure its survival into the next millennium? How can I see it for itself?

Recommendations that biologists could follow for an immediate reduction in carbon emissions (I would like to acknowledge a colleague Stefi Barna for suggesting the titles):

1. Scientists Strike for Zero Carbon Conferencing by 2030

Cancel the annual meetings of the Annual Society for Cell Biology and Society for Neuroscience for 2020 while holding press meetings on the reasons for canceling these meetings (response to planetary ecological collapse). These are amongst the largest meetings of biologists, and canceling these meetings will send a strong message to other scientists of the need to tackle this problem. Urge colleagues attending APS, ACS and Gordon conferences to start similar movements in their disciplines. Calculate the carbon emissions for 2019 and set a target of reducing them by $90 \%$ in 2 years after conferences resume in 2021.

2. Zero Carbon Scientific Publications by 2030

Every journal should require authors to report an estimate of carbon emissions produced in researching and writing their paper (including commute and conference travel). This metric while not to be used for any decision making process on the paper will highlight the importance of always keeping in mind this all important numerare. In the near future recording carbon emissions associated with particular activities is probably going to be become as commonplace as recording temperature. I have calculated my $\mathrm{CO}_{2} \mathrm{e}$ at approx $885 \mathrm{~kg}$, using a time duration of 6 months for conceiving and writing this article. A majority of my emissions come from commuting. This number is fairly high if compared to the per capita $\mathrm{CO}_{2} \mathrm{e}$ for India at $1640 \mathrm{~kg}$.

3. Zero Carbon Knowledge Production by 2030

Explicitly ask new faculty to include in their research statement measures they will be taking to reduce carbon emissions and increase sustainability measures while conducting their research.

4. Zero Carbon Academic Activity by 2030

Let established/leading scientists pledge to decrease the carbon emissions of their departments/institutes by $50 \%$ in the next two years and devote at least $25 \%$ of their time to this mission.

\section{References}

[1] G. V. Bosco, Voice of a Sentient Highland. Partridge Publishing India, 2019.

[2] T. E. Lovejoy, "Look back lest you fail to mark the path ahead," PLANTS, PEOPLE, PLANET, vol. 1, pp. 71-76, Apr. 2019.

[3] D. Spinellis and P. Louridas, "The Carbon Footprint of Conference Papers," PLoS ONE, vol. 8, p. e66508, June 2013.

[4] J. Nathans and P. Sterling, "How scientists can reduce their carbon footprint," eLife, vol. 5, p. e15928, Mar. 2016. 
[5] S. Buranyi, "Is the staggeringly profitable business of scientific publishing bad for science?," The Guardian, June 2017.

[6] N. S. Young, J. P. A. Ioannidis, and O. Al-Ubaydli, "Why Current Publication Practices May Distort Science,” PLOS Medicine, vol. 5, p. e201, Oct. 2008.

[7] A. R. Aron, "The climate crisis needs attention from cognitive scientists," Trends in Cognitive Sciences, 2019.

[8] S. Wynes, S. D. Donner, S. Tannason, and N. Nabors, "Academic air travel has a limited influence on professional success,” Journal of Cleaner Production, vol. 226, pp. 959-967, July 2019.

[9] N. R. Council, Himalayan Glaciers: Climate Change, Water Resources, and Water Security. Washington, DC: The National Academies Press, 2012.

[10] Alison Green et al., "Facts about our ecological crisis are incontrovertible. We must take action | Letters,” The Guardian, Oct. 2018.

[11] Vandana Shiva et al., "Act now to prevent an environmental catastrophe | Letter," The Guardian, Dec. 2018.

[12] Bennett Carys E., Thomas Richard, Williams Mark, Zalasiewicz Jan, Edgeworth Matt, Miller Holly, Coles Ben, Foster Alison, Burton Emily J., and Marume Upenyu, "The broiler chicken as a signal of a human reconfigured biosphere," Royal Society Open Science, vol. 5, no. 12, p. 180325.

[13] V. Bush, United States, and Office of Scientific Research and Development, Science, the endless frontier: a report to the President. 1945. OCLC: 1594001.

[14] M. Gagliano, Thus spoke the plant: a remarkable journey of groundbreaking scientific discoveries and personal encounters with plants. Berkeley, California: North Atlantic Books, 2018.

[15] S. Brenner, “Turing centenary: Life's code script,” Nature, vol. 482, pp. 461-461, Feb. 2012. 